\title{
Impact of Earnings, Book Value and Dividend on Market Price of Stock of Nepalese Manufactur- ing Firms Listed In NEPSE
}

\author{
Bashu Neupane \\ Lecturer, Nepal Commerce Campus, T.U.
}

\begin{abstract}
The main purpose of this study is to analyze the impact of EPS, DPS, BPS, and $P / E$ ratio on the stock price of manufacturing firms listed in NEPSE from 2072 to 2076. In this study, the data of four manufacturing firms listed in NEPSE have been studied. The descriptive and causal-comparative research designs were used to analyze the impact of EPS, DPS, BPS, and P/E ratio on MPS. The DPS and $B P S$ negative significant impact on the stock price of the market and the EPS and $P / E$ ratios are insignificant so they cannot predict the stock price of the market. The study also revealed that the valuable stock is UNI-Lever and the more risky firm is SHIVM cement on the study of manufacturing firms, listed in NEPSE.
\end{abstract}

Keywords: NEPSE, Manufacturing firms, Earning per share, Dividend per share, Book value per share, Price-earnings ratio, and Market price of the stock.

\section{Introduction}

Investment is the main activity of investors to generate future earnings. The two types of assets are available in the market to invest in. They are real assets and financial assets. The firms acquire physical assets to operate business activities and to produce quality work and generate future earnings. But the individual investors invest their funds in financial assets. Individual investors invest their funds for two purposes i.e., future earnings and liquid easily wherever required. So, investment in shares is one of the most important activities of individual investors. Basically, the firms' main goal is to maximize the shareholder's wealth. The shareholders' wealth can be maximized by increasing the net present value of the firm. Stock returns are considered the most important factors that are used to determine the best investment alternatives. Thus, investors usually depend on returns and want to avoid risk while making investing decisions. The information about the stock can be received from an internal or external source. The internal information can be obtained from the financial reports while external information can be found in the stock market and website. When investing in stocks, investors should take into consideration various information about risk and return about the investment when they wish to liquidate assets. Thus, investors aim to realize normal gain and capital gain. The ratio analysis is the most important tools to analyze the financial statement which inform a lot of information on the internal position of a firm. The earning shows how much the firm's ability to generate income for the shareholders. Therefore, earning and the dividend may attract the shareholders because it is used as an indicator to measure the earning capacity of the firms.

Westen, G., (1989) studied the investor behaviour towards shares is influenced by accounting information represented by EPS, DPS, and P/E ratio as a reflection of financial performance. Stock market prices are one of the most important factors that influence investors' investment decisions.

Glezakos, et al. (2012) expressed that the common stocks generally may give more attention to 
earnings per share and dividend per share which turns to affect the price of shares in the market to obtain capital gains.

Stock price in the market depends on the demand and supply of stock, which depends on the financial performance of a firm. In general, stock prices reflect the financial performance of the firm. Both economic and non-economic factors may influence the volatility of the stock price. Financial ratios are one of the important tools to measure financial performance in measuring the firm's success or failure.

Market value ratio indicates the investors about the firms' performance and prospects. The priceearnings ratio and price-book value can be used to measure the market value of the stock. The Priceearnings ratio $(\mathrm{P} / \mathrm{E})$ indicates the investor's attention and the firms' possibility of growth that may reflect in the stock price. The higher $\mathrm{P} / \mathrm{E}$ ratio indicates that investors have good expectations about the firms' development in the future, so for certain earnings per share, investors are willing to pay a high price. Price to book value (PBV) describes how much the book value of a firms' stock is valued by the market. A high BPS shows that the more successful firm attracts the shareholders. The firms' performance reflected in the high BPS, the firm is increasingly successful in creating value for shareholders and the amount of profit to shareholders will increase. Besides that, the high BPS makes the market more confident about the firm's prospects, so that investors will be interested in investing their funds into the firm.

Olugbenga and Atanda (2014) concluded that a significant positive relation between PBV and EPS. EPS is generally considered to be the most significant variable in determining the stock price. Hence, it plays an important role in measuring stock price.

\section{Problem Statement}

Most of the studies of the relation between stock price and earning are found in developed financial markets; very few studies are done in emerging financial markets, like Nepal. This study has been examined the effect of earning per share, dividend per share, book value per share, and price-earnings ratio on the stock price. Thus, the study deals with the following issues:

1) There is any relation between EPS, DPS, and MPS?

2) Is there any impact of DPS and P/E ratio on MPS?

3) Is the EPS, DPS, BPS, P/E ratio may influence the MPS?

\section{Objective of the Study}

The study objective is to analyze the impact of earning per share, dividend per share, book value per share, and price-earnings ratio on the market price of the stock.

\section{Hypothesis of the Study}

Based on previous studies, the following alternative hypothesis has been formulated to test them. They are:

H1a: Earnings per share (EPS) have a significant effect on the stock price.

H1b: Dividend per share (DPS) has a significant effect on stock prices.

H1c: Book value per share has a significant effect on stock prices.

H1d: Price/earnings ratio (P/E) has a significant effect on stock prices.

\section{Review of Literature}

Seetharaman and Rudolph (2011) explored the impact of earnings per share, dividend per share on market price is significant stock price movements, thus, asserting that there is a significant relationship between stock prices and earnings per share.

Sharma (2012) examined the relation of the market price of the stock on book value, dividends, earnings, $\mathrm{P} / \mathrm{E}$ ratio; dividend yield $(\mathrm{D} / \mathrm{Y})$, there was a positive relationship between the variables considered in the study. 
Malhotra and Tandon (2013) analyzed the effects of book value per share, earnings per share, dividends per share, dividend yield, and price-earnings ratio from the company's stock price registered at NSE 100. The research findings for the 2007- 2012 period revealed that BPS, EPS, and P/E ratio have a significant positive relationship with the stock price while the dividend yield is a significant negative relation with the stock price of the market.

Glezakos, et al. (2014) studied the market prices (MPS), EPS and DPS of the stock market of three sectors. The study conducted three sectors, namely the primary sector, manufacturing, and services in India and the research findings determined that there was a statistically significant positive relationship between EPS and stock market prices.

Arslan and Zaman (2016) examined the effect of EPS and BPS on the stock price. This study used regression techniques in 19 banks from the period 2008 to 2012. The findings showed a strong impact of EPS and DPS on MPS. There is a negative impact between BPS and Stock Prices of the market as well as earnings per share. The EPS is more relevant than the book value.

Kheradyar and Ibrahim (2015) examined the effect of EPS on Banking Stock Prices listed on the Indonesia Stock Exchange in 2010- 2014. The findings of this study, EPS influenced the stock prices. Partially, EPS has a positive and significant effect on the stock price.

Pradhan (2017) examined the stock market behaviour of NEPSE. The effect of dividend bubbles on the share price of Nepalese commercial banks. The market price per share may fluctuate on the dividend per share and earnings per share. The study concluded that larger stocks have a larger price-earnings ratio, a larger book to market value, lower liquidity, and lower profitability, and smaller dividend.

Warrad, L.H. (2017) examined the effect of market forces on Jordanian banks' stock prices from 2008 through 2014; the study applied correlation and multi-regression methods to test its hypotheses. The independent variables for the study are earnings (EPS), dividends (DPS), the book value of share (BPS), price/earnings ratio ( $\mathrm{P} / \mathrm{E}$ ratio), and the stock price of the market. The results showed that market price measures a significant effect on banks' stock prices. Dividends (DPS), the book value of the share, and dividend yield have a significant effect on stock price, while there was no significant effect caused by EPS, $\mathrm{P} /$ E ratio.

Chisti et al. (2018) analyzed the impact of EPS, DPS and P/E ratio on the stock price. The sample used the sixteen companies representing four different industries. The period was taken for eight years from 2003-2011. To achieve the objectives of the study the regression analysis and correlation analysis have been used. The research findings confirm that there is a positive relationship between EPS and stock market prices on the other hand EPS is not statistically affecting PER.

\section{Research Variables}

This research was conducted to test the hypothesis of the variable consisting of the dependent variable and the independent variable that has relevance. The independent variables are EPS, DPS, BPS, and P/E ratio while the dependent variable is the stock price.

Earnings per share (EPS) are calculated as a firms' profit divided by the outstanding number of shares. The resulting number serves as an indicator of a company's profitability. It is common for a company to report EPS that is adjusted for extraordinary items and potential share dilution. The higher a company's EPS, the more profitable it is considered to be. This describes the profitability of the firm that is reflected in stock price.

Dividend per share (DPS) is the sum of declared dividends issued by a firm for every ordinary share outstanding. This is calculated by dividing the total dividends paid out by a business, including interim dividends, over a period of time by the number of outstanding shares.

Book value per share (BPS) is a method to calculate the per-share book value of a firm based on common shareholders' in the firm. The book value of a firm is the difference between total assets and total liabilities of the firm. 
The price-to-earnings ratio ( $\mathrm{P} / \mathrm{E}$ ratio) is one of the most important stock analysis tools used by investors and analysts for stock valuation. It determines the firm's stock price is overvalued or undervalued.

\section{Independent Variables}

The market price of stock or stock price (MPS) is the value of the firm in which the stock is traded in the secondary market. Every publicly traded firm issues its shares to the general public and they are liquidated in the secondary market. The stock price is determined by the demand and supply of shares. The price of a stock will go up and down about several different factors, including changes within the economy as a whole, changes within industries, political events, and environmental change

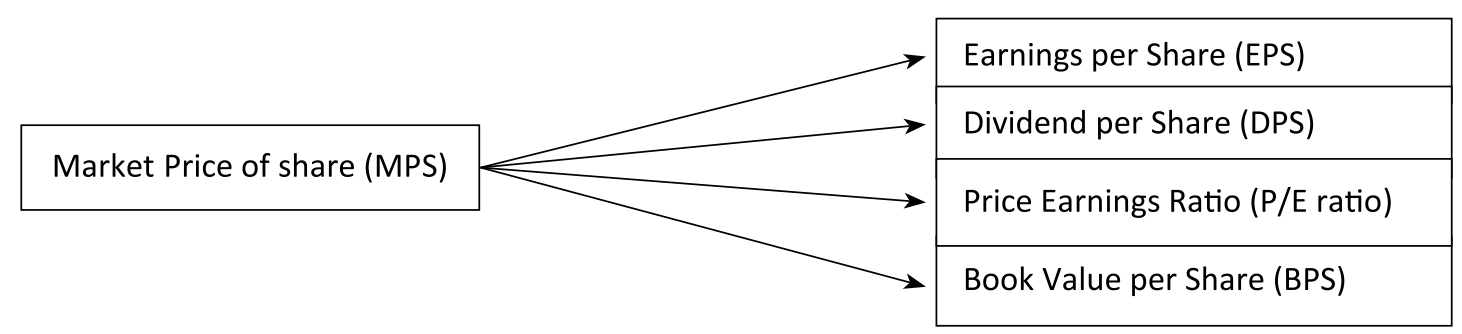

\section{Research Methodology}

The research methodology is the overall plan associated with a study. It provides a basic framework on which the study is based. This study is designed to obtain the answer to the research problems. This consists of descriptive and causal-comparative research design to deal with the various issues of the study. This study is mainly based on secondary data. The listed all four manufacturing firms are included in the study. So, the population of the study is four and all four firms are studied as samples. The monthly market price of the stock (MPS) of listed manufacturing firms is collected from trading reports published by the Securities Board of Nepal (SEBON) and the Nepal Stock Exchange (NEPSE). The data sets are used in monthly closing prices. The study period covers the time period of 54 months, from Baisakh 2072 to Ashoj 2076. The study cannot cover 2077 because of covid-19. This affected the secondary market and most of the period the secondary market closed. If this period is included in the study the result may not consistent with previous results. The statistical package for social sciences (SPSS) version 23 software has been used to analyze the secondary data.

\section{Model Specification}

To find out the impact of earnings per share, dividend per share, book value per share and priceearnings ratio on stock price, the following model has been specifying the literature.

$$
\mathrm{Y}(\mathrm{MPS})=\beta 0+\beta 1 \mathrm{EPS}+\beta 2 \mathrm{DPS}+\beta 3 \square \mathrm{PS}+\mathrm{B} 4 \mathrm{P} / \mathrm{E} \text { ratio }+\square \text { it }
$$

Where $\beta 0=$ intercept $/$ constant

$\beta 1, \beta 2$ and $\beta 3$ are the coefficients of the independent variable i.e., EPS, DPS, BPS, P/E ratio respectively

$\square \mathrm{it}=$ Error term i.e., value $=0$.

\section{Results and Findings}

\section{Descriptive statistics}

A descriptive statistic is described or summarized the features of a collection of quantitative information, while descriptive statistics is the process of using and analyzing those statistics. Descriptive statistics are distinguished from inferential statistics by its aim to summarize a sample, rather than use the data to learn about the population that the sample of data is thought to represent. 
Table-1

Mean and Standard Deviation

\begin{tabular}{lcccccccc}
\hline \multirow{2}{*}{ Var } & BNB & BNT & SHIVM & UNI & \multirow{2}{*}{ BNB $\sigma$} & BNT $\Sigma$ & SHIVM $\Sigma$ & UNI $\Sigma$ \\
& Mean & Mean & Mean & Mean & & & & \\
\hline MPS & 2213.3 & 6636.7 & 600.9 & 20663.6 & 349.4 & 374.8 & 215.6 & 5315.8 \\
EPS & 681.1 & 828.4 & 22.4 & 921.3 & 29.4 & 138.4 & 3.6 & 112.2 \\
DPS & 21.7 & 32.5 & 12.9 & 940.0 & 2.4 & 8.7 & 3.3 & 259.4 \\
BPS & 2035.5 & 2024.5 & 167.5 & 2500.1 & 138.5 & 117.5 & 25.2 & 230.2 \\
P/E & 2.8 & 6.5 & 22.9 & 16.7 & 0.5 & 0.7 & 5.5 & 1.5 \\
\hline
\end{tabular}

Based on descriptive statistics, the highest stock price is Rs. 20663.6, the highest annual EPS is Rs. 921.30, the highest annual dividend per share is Rs. 940 distributed to its shareholders, and the highest book value is Rs. 2500.1 of UNI lever Nepal Limited. But the highest P/E ratio 22.93 times of SHIVM cement limited.

Table-2

Coefficient of Variation (C.V.)

\begin{tabular}{lcccc}
\hline Variables & BNB & BNT & SHIVM & UNI \\
\hline MPS & 0.157 & 0.056 & 0.359 & 0.257 \\
EPS & 0.043 & 0.167 & 0.162 & 0.122 \\
DPS & 0.109 & 0.266 & 0.259 & 0.276 \\
BPS & 0.068 & 0.058 & 0.150 & 0.092 \\
P/E Ratio & 0.175 & 0.109 & 0.240 & 0.087 \\
\hline
\end{tabular}

Based on the coefficient of variation, the consistent MPS is Bottlers Nepal Terai during the study period, but the more variation of the stock price is SHIVM cement limited. Consistent EPS is Bottlers Nepal Balaju, Uniformity DPS is distributed to its shareholders by Bottlers Nepal Balaju. The consistent BPS is Bottlers Nepal Terai from 2015 to 2019. The uniformity in P/E ratio is UNI lever limited during the study period. While analyzing the coefficient of MPS of SHIVM cement is greater than other manufacturing firms so, its price is riskier than other firms' MPS.

\section{Regression Analysis}

In statistical modeling, regression analysis is a set of statistical processes for estimating the relationships between a dependent variable and independent variables. It is used to predict the value of a dependent variable based on the value of two or more independent variables. In linear regression, the relationship is constrained to be a straight line and least-squares analysis is used to determine the best fit.

Table-3

Model Summary of Bottlers Nepal Balaju

\begin{tabular}{lcccc}
\hline Model & $\mathrm{R}$ & $\mathrm{R}$ Square & Adjusted R Square & Std. Error of the Estimate \\
\hline 1 & -0.810 & 0.656 & 0.549 & 124.631 \\
\hline
\end{tabular}

a. Predictors: (Constant), P/E Ratio, BPS, DPS

b. Dependent Variable: MPS

The coefficient of determinants is 0.656 is the variation of the dependent is the proportion of variance in the dependent variable stock price explained by the independent variables. The independent variables $65.6 \%$ explained the dependent variable. The $\mathrm{R}$ square of more than 0.5 can explain the dependent variable 
Issue 1 May/June 2020

by the predictors.

Table-4

ANOVA Table of Bottlers Nepal Balaju

\begin{tabular}{llccccc}
\hline Model & Sum of Squares & Df & Mean Square & F & Sig. \\
\hline 1 & Regression & 318653.294 & 4 & 79663.324 & 43.051 & 0.000 \\
& Residual & 90671.873 & 49 & 1850.446 & & \\
& Total & 409325.167 & 53 & & & \\
\hline
\end{tabular}

a. Dependent Variable: MPS

b. Predictors: (Constant), P/E Ratio, BPS, DPS

ANOVA table of multiple regression showed $\mathrm{F}(4,49)=43.051, \mathrm{p}<.001$, indicating at least one predictors' slope coefficient is statistically significant. This table describes that the DPS and BPS have significant negative regression coefficients and the $\mathrm{P} / \mathrm{E}$ ratio has a negative coefficient but not significantly predict the stock price. But, the predictor EPS cannot predict the stock price. So, it is excluded while estimating the model.

$$
\mathrm{Y}(\mathrm{MPS})=7590.995-10.57 \mathrm{DPS}-2.07 \text { BPS- 334.39 P/E ratio }+\square \text { it }
$$

The EPS has been excluded by the model to predict the MPS. The DPS and P/E ratio has a significant negative impact on MPS so, the null hypothesis should not be accepted, but BPS has no significant impact on MPS so, the alternative hypothesis should not be accepted.

Table-5

Model Summary of Bottlers Nepal Terai

\begin{tabular}{lllll}
\hline Model & R & R Square & Adjusted R Square & Std. Error of the Estimate \\
\hline 1 & -0.768 & 0.591 & 0.396 & 91.05 \\
\hline
\end{tabular}

a. Predictors: (Constant), P/E Ratio, Book Value, Annual Dividend

b. Dependent Variable: MPS

The coefficient of determinants is 0.591 is the variation is the proportion of variance in the dependent variables' stock price explained by the independent variables. The independent variables $59.1 \%$ explained the dependent variable. The $\mathrm{R}$ square of more than 0.5 can explain the dependent variable by the predictors.

Table-6

ANOVA Table of Bottlers Nepal Terai

\begin{tabular}{lllllll}
\hline Model & & Sum of Squares & Df & Mean Square & F & Sig. \\
\hline 1 & Regression & 421485.355 & 4 & 105371.339 & 36.264 & 0.000 \\
& Residual & 142378.040 & 49 & 2905.674 & & \\
& Total & 563863.395 & 53 & & & \\
\hline
\end{tabular}

a. Dependent Variable: MPS

b. Predictors: (Constant), P/E Ratio, Book Value, Annual Dividend

ANOVA table of multiple regression showed $\mathrm{F}(4,49)=36.264, \mathrm{p}<.001$, indicating at least one of the predictors' slope coefficient is statistically significant. Two predictors DPS and P/E ratio has a significant negative impact on MPS; the null hypothesis should not be accepted. The BPS has no significant impact on MPS; so, the BPS cannot predict the MPS. The predictor EPS cannot predict the stock price because the model excluded it to estimate the MPS.

$$
\mathrm{Y}(\mathrm{MPS})=11641.35-11.30 \mathrm{DPS}-1.25 \text { BPS- } 324.82 \mathrm{P} / \mathrm{E} \text { ratio }+\square \text { it }
$$


The EPS has been excluded by the model so; the alternative hypothesis should not be accepted. The DPS and BPS have a significant negative impact on MPS. Hence, the null hypothesis should be rejected. But the BPS has not a significant effect on stock price so; the alternative hypothesis should be rejected.

Table-7

Model Summary of SHIVM Cement

\begin{tabular}{lcccc}
\hline Model & $\mathrm{R}$ & R Square & Adjusted R Square & Std. Error of the Estimate \\
\hline 1 & 0.783 & 0.613 & 0.542 & 87.941 \\
\hline
\end{tabular}

a. Predictors: (Constant), P/E Ratio, Annual EPS, Book Value

b. Dependent Variable: MPS

The coefficient of determinants is 0.613 is the variation of the dependent is the proportion of variance in the dependent variable stock price explained by the independent variables. The independent variables $61.3 \%$ explained the dependent variable. The $\mathrm{R}$ square of more than 0.5 can explain the dependent variable by the predictors.

Table- 8

ANOVA Table of SHIVM Cement

\begin{tabular}{lllllll}
\hline Model & & Sum of Squares & Df & Mean Square & F & Sig. \\
\hline 1 & Regression & 139439.984 & 4 & 34859.996 & 95.14 & 0.000 \\
& Residual & 17839.715 & 49 & 364.076 & & \\
& Total & 139439.984 & 53 & & & \\
\hline
\end{tabular}

a. Dependent Variable: MPS

b. Predictors: (Constant), P/E Ratio, Annual EPS, Book Value

ANOVA table of multiple regression showed $\mathrm{F}(4,49)=95.14, \mathrm{p}<.001$, indicating at least one of the predictors' slope coefficient is statistically significant. The two predictors DPS and P/E ratio has significant negative regression coefficients and the P/E ratio has a negative coefficient and significant impact on MPS similarly book value has a positive impact on the stock price but not significant. Similarly, the EPS has a positive impact but not significant.

$$
\mathrm{Y}(\mathrm{MPS})=560.50-35.94 \mathrm{DPS}+10.39 \mathrm{EPS}-8.48 \mathrm{BPS}-70.40 \mathrm{P} / \mathrm{E} \text { ratio }+\square \text { it }
$$

The EPS and BPS have not a significant impact on MPS; the alternative hypothesis should not be accepted. But the DPS and P/E ratio have a significant impact on MPS the null hypothesis should not be accepted.

Table-9

Model Summary of Unilever

\begin{tabular}{lllll}
\hline Model & R & R Square & Adjusted R Square & Std. Error of the Estimate \\
\hline 1 & 0.889 & 0.790 & 0.764 & 104.673 \\
\hline
\end{tabular}

a. Predictors: (Constant), P/E Ratio, Annual EPS, Book Value

b. Dependent Variable: MPS

The coefficient of determinants is 0.790 is the variation of the dependent variable. It is the proportion of variance in the dependent variable MPS explained by the independent variables. The independent variables $79 \%$ predict the dependent variable. The $\mathrm{R}$ square more than 0.5 so, it can explain the dependent variable by the predictors. 
Issue 1 May/June 2020

Table-10

ANOVA Table of Unilever Limited

\begin{tabular}{lllllll}
\hline Model & & Sum of Squares & Df & Mean Square & F & Sig. \\
\hline 1 & Regression & 84774117.72 & 4 & 21193529.43 & 83.45 & 0.000 \\
& Residual & 5660829.02 & 49 & 115527.12 & & \\
& Total & 84774117.72 & 53 & & & \\
\hline
\end{tabular}

a. Dependent Variable: MPS

b. Predictors: (Constant), P/E Ratio, Annual Dividend, Annual EPS

ANOVA table of multiple regression showed $F(4,49)=83.451, p<.001$, indicating at least one of the predictors' slope coefficient is statistically significant. The predictor DPS and P/E ratio have an inverse impact on MPS. The EPS has a positive impact on the stock price. Similarly, the BPS has been excluded from the model by the stepwise regression model.

$$
\mathrm{Y}(\mathrm{MPS})=156129.83-22.38 \mathrm{DPS}+23.23 \mathrm{EPS}-812.86 \mathrm{P} / \mathrm{E} \text { ratio }+\square \text { it }
$$

The BPS has been excluded by the model so; the alternative hypothesis should not be accepted. The DPS and P/E ratio has a significant negative impact on MPS. Hence, the null hypothesis should be rejected. But the EPS has not a significant effect so; the alternative hypothesis should be rejected.

\begin{tabular}{lcccc}
\hline Alternative Hypothesis & $\begin{array}{c}\text { Decision } \\
\text { BNB }\end{array}$ & $\begin{array}{c}\text { Decision } \\
\text { BNT }\end{array}$ & $\begin{array}{c}\text { Decision } \\
\text { SHIVM }\end{array}$ & $\begin{array}{c}\text { Decision } \\
\text { UNI-Lever }\end{array}$ \\
\hline $\begin{array}{l}\text { H1a: Earnings per share have significant effect on } \\
\text { stock price. }\end{array}$ & Rejected & Rejected & Rejected & Rejected \\
$\begin{array}{l}\text { H1b: Dividend per share has significant effect on } \\
\text { stock prices. }\end{array}$ & Accepted & Accepted & Accepted & Accepted \\
$\begin{array}{l}\text { H1c: Book value per share has significant effect } \\
\text { on stock prices. }\end{array}$ & Rejected & Rejected & Rejected & Rejected \\
$\begin{array}{l}\text { H1d: Price/earnings ratio has significant effect on } \\
\text { stock prices. }\end{array}$ & Accepted & Accepted & Accepted & Accepted \\
\hline
\end{tabular}

\section{Discussion}

The MPS of UNILEVER is greater than the other manufacturing firms. It is a more valuable stock than other manufacturing firms. The coefficient of variation of MPS of SHIVM cement is more than the other firms. This shows that the MPS fluctuates more than the other manufacturing firms hence; it is riskier than other firms.

The DPS and P/E ratio have predictive power on the MPS of manufacturing firms listed in NEPSE. The BPS and EPS cannot predict the MPS of manufacturing firms listed in NEPSE. The result of DPS and Price-earnings ratio has a similar result with the previous study. The result of BPS and EPS has a similar result to the previous study. At last, the predictor's EPS and BPS cannot predict the MPS of manufacturing firms listed in NEPSE. But the predictors DPS and P/E ratio has a positive impact on the MPS of manufacturing firms listed in NEPSE.

\section{Conclusion}

This study analyzed the impact of earning per share, dividend per share, book value per share, and price-earnings ratio on the market price of the stock of four Nepalese manufacturing firms listed in NEPSE. The study analyzed the panel data for the period of 54 months from 2072 to 2076. Earnings per share, Dividend per share, Book value per share, and price-earnings ratio were used as independent variables and a stock price of the market as the dependent variables. The results of this study support the hypothesis that 
is a significant negative impact of DPS and EPS on the stock price. But the EPS and BPS hypothesis have no significant impact on the stock price. This study also revealed that if any firm pays more dividends its market price will decrease. This study also revealed that the UNI- Lever share is more valuable than the other manufacturing firms. But the market price of SHIVM cement is more fluctuated than other manufacturing firms. So, the stock price of SHIVM cement is riskier than other manufacturing firms.

\section{Limitations of the Study}

This study focused on quantitative characters of the secondary market of Nepal. This study analyzed the impact of EPS, DPS, BPS, and P/E ratio on the market price of the stock of manufacturing firms listed in NEPSE. It covered the monthly financial data from 2072 to 2076 (54 months) but the covid-19 effect period included in this study, the result may different than previous results. If more periods are included in the study the result may differ. Similarly, more manufacturing firms are included in the study the results may also differ.

\section{References}

Arslan, M. and Zaman, M. (2016). Impact of dividend and price-earnings ratio on stock price: A study nonfinancial listed firms of Pakistan. Research Journal of Finance and Accounting, vol. 11((2) , 96-109.

Chisti, A. et al. (2018). Predictability of stock price using financial ratios in the companies listed in the Columbia stock exchange. International Research Journal of Applied and Basic Science, vol.4, 234251.

Glezakos, V., et al. (2014). The impact of accounting information on the stock price. International Journal of Economics and Finance, vol. 4(2), 68-87

Kheradyar, S. and Ibrahim, U. (2015). Stock price predictability with the financial market. International Journal of Trade Economics and Finance, vol. 2, 143- 161.

Malhotra, B. and Tandon, K. (2013). The relevance of accounting information on investor decision. Accounting and Financing, vol. 18 (3), 1-49.

Olugbenga, A. and Atanda E. (2014). Value relevance of financial accounting information of quoted companies in Nigeria: a trend analysis. Research Journal of Finance and Accounting, vol. 8, 149-184.

Pradhan, R. S. (2017). The effect of a dividend bubble on share Price: A case of Nepalese commercial banks. Monetary Economics: Financial System \& Institutions eJournal, 33-46.

Seetharaman, N. and Rudolph, J. R. (2011). An empirical study on the impact of earnings per share on stock prices of a listed bank in Malaysia. The International Journal of Applied Economics and Finance. vol. $5,(2), 114-126$.

Sharma, S. (2012). Determinants of equity share prices in India. Journal of Arts, Science and Commerce, vol.II, issue 4, 51-60.

Westen, G. (1989). Effect of performance evaluation market price of a stock in Austria. Journal of Economic, Finance and Accounting for Applied Science, vol. 16 (2), 76-95.

Warrad, L.H. (2017). The Effect of market valuation measures on stock price: An empirical investigation on Jordanian banks. International Journal of Business and Social Science vol. 8 (3), 67-74. 
Issue 1 May/June 2020 - 